\title{
THE U.S. WITHDRAWAL FROM THE OPEN SKIES TREATY
}

\author{
Nikolai Sokov* \\ Vienna Center for Disarmament and Nonproliferation
}

ORCID: 0000-0002-4723-8089

(C) N.Sokov, 2021

DOI: 10.20542/2307-1494-2021-1-133-150

\begin{abstract}
The article analyzes the dynamics, causes and implications of the collapse of the Open Skies Treaty in the broader context of gradual dismantlement of the network of arms control and confidence building regimes created at the end of the Cold War. The central focus is on the explanation of the declining U.S. support for the treaty since the 2010s and the eventual withdrawal addressed against the background of the evolution of the U.S. approach to arms control during the first two decades of the 21st century. While policies changed from one president to another, a sequence of U.S. administrations shared growing loss of interest in arms control and unwillingness to invest in generating domestic support for existing and new agreements. The weakening of arms control became preferable to limitations on the U.S.' own programs and forces, in line with the belief that the United States was sufficiently advanced to remain ahead of any possible competitors, including Russia. While arms control issues are more effectively addressed through detailed, difficult negotiations and compromises, the evolving U.S. approach to perceived treaty violations by Russia amounted to an ultimatum to Moscow to admit violations and fix them the way the U.S. wants them to be fixed. Russia's decision to follow suit by withdrawing from the treaty, while not immediate or preordained, is explained as driven both by political motives and, in cost-benefit terms, by concerns that the United States would keep access to data on Russia collected under the treaty through the U.S. NATO allies. The prospects for modest upgrade of the arms control agenda under the Biden administration are also addressed.
\end{abstract}

Keywords Open Skies Treaty, the Open Skies Consultative Commission, United States, Soviet Union, Russia, overflights, transparency, confidence-building measures, compliance, violations, withdrawal, arms control, U.S.-Russia relations

\section{Название Выход США из Договора по открытому небу статьи}

\footnotetext{
* Nikolai Sokov is Senior Fellow at Vienna Center for Disarmament and Nonproliferation, Austria.

Соков Николай Николаевич - старший научный сотрудник Венского центра изучения проблем разоружения и нераспространения, Австрия, доктор политических наук.
} 
Аннотация $\mathrm{B}$ статье анализируются динамика, причины и последствия развала Договора по открытому небу на фоне постепенного демонтажа системы режимов по контролю над вооружениями и укреплению доверия, созданной на исходе «холодной войны». Центральное внимание уделено объяснению выхода США из договора в контексте эволюции американских подходов к контролю над вооружениями в течение первых двух десятилетий XXI в. Хотя конкретная политика в этой сфере варьировалась от одного президента к другому, череду администраций США объединяла постепенная потеря интереса к вопросам контроля над вооружениями и нежелание инвестировать в создание внутриполитической поддержки как действующих, так и новых договоренностей. В силу веры в то, что военно-технологическое превосходство США позволяет им оставить позади любых конкурентов, включая Россию, для Вашингтона ослабление контроля над вооружением стало предпочтительней любых ограничений американских национальных программ и сил. Хотя вопросы контроля над вооружениями наиболее эффективно решаются путем детальных, трудных переговоров и компромиссов, подход США к предполагаемым ими нарушениям договора со стороны России свелся к ультимативному требованию к ней безоговорочно признать и исправить их именно так, как предписано Вашингтоном. Решение России вслед за США также выйти из договора, которые было принято не сразу и не было предопределено, автор объясняет как политическими мотивами, так и, в частности, российской обеспокоенностью тем, что США через своих союзников по НАТО сохранят доступ к информации, собранной о России в рамках инспекционных полетов по договору. В статье также оцениваются перспективы некоторого оживления повестки дня в сфрере контроля над вооружениями при администрации Дж.Байдена.

Ключевые Договор по открытому небу, Консультативная комиссия по открытому небу, США, слова

СССР, Россия, полеты над чужой территорией, транспарентность, меры укрепления доверия, соблюдение, нарушения, выход, контроль над вооружениями, американо-российские отношения

\section{Introduction}

The almost certain collapse of the Open Skies Treaty (OST) ${ }^{1}$ is a momentous event: it effectively represents the collapse of the first transparency and confidence building idea of the modern world. The concept of aerial monitoring system that opened the territory of each participant for international inspection was first proposed by President Dwight Eisenhower during the four-party conference (the United States, the Soviet Union, the United Kingdom, and France) in Geneva in 1955. However, during the early years of the Cold War, such a regime was unthinkable, and the concept of open skies remained dormant for three decades until U.S. president George W. Bush, to the surprise of many, revived it in 1989. Negotiations took three years and survived tectonic changes in the international system the breakup first of the Warsaw Pact and then of the Soviet Union - to be concluded in 1992.

The entry into force of OST was delayed until January 1,2002 to a large extent because of ratification delay in Russia: following the old tradition, many in Russia regarded OST a tool for legitimized spying (the reason why the original Eisenhower's initiative was rejected, too). Yet, many provisions of OST entered into force soon after the signing, including the so-called trial observation flights (about 400 such flights in total were made by 
the Treaty's entry into force). Russia participated in trial flights which helped demonstrate the usefulness of the new regime to Moscow, especially since the Russian constellation of surveillance satellites was dwindling. Over time, Moscow seemed more and more committed to OST - to the extent of dedicating special aircraft to that end, equipped with the most advanced observation and monitoring systems, "Tu-214ON". Europe has been very supportive of the treaty from the very beginning, in no small extent because it relied on overflight rights to independently collect data about security-related developments in Russia and Belarus (NATO countries agreed not to conduct flights over each other's territories). Within the United States, however, support for OST began to decline by the 2010s at an accelerated pace. The administration headed by Donald Trump espoused a skeptical attitude toward all existing arms control treaties, at best, that resulted, among other steps, in the U.S. withdrawal from OST. After that, Russian withdrawal was only a matter of time.

\section{United States on the path toward withdrawal}

The official reason for the U.S. withdrawal from OST was incompliance of Russia with its obligations under the treaty. There were multiple instances of such claims. Some were resolved and remained in the past, some emerged in the recent years. The most tangible of these were:

- A $500 \mathrm{~km}$ limit on flights over Kaliningrad exclave of the Russian territory; ${ }^{2}$

- Russia's refusal to allow flights within the 10-km corridor along the Russian border with Abkhazia and South Ossetia: since Russia recognizes them as independent states, the provision about a ban of flights within the $10-\mathrm{km}$ zone of a state that is not party to OST appears to apply. Since the United States and NATO do not recognize these territories as part of Georgia, which is a party to OST, the United States claimed such flights should have been allowed. ${ }^{3}$

- At different times, the United States also complained about altitude restrictions (over Moscow and, until 2016, Chechnya) as well as denial of observation flights with references to force majeure, including flights during large-scale military exercises, starting from $2013 .{ }^{4}$ The most recent event in that category was denial of the second phase of the overflight during the "Tsentr-2019" military exercises, which Russia explained by the challenges of ensuring the safety of the OST aircraft under conditions of intense air traffic.

- In addition, although not formally designated as a compliance issue, in 2014 Russia designated a new refueling point in the Crimea, which the United States as well as other parties to OST did not recognize as part of the Russian territory. The Crimea issue belongs more properly to the Vienna Document domain, ${ }^{5}$ but it is often cited also in the context of OST.

Obviously, Russia had concerns of its own. These concerns were primarily related to the denial by the United States of the ability to land at certain U.S. bases to provide rest for crews (endangering the safety of flights), limits on distance of flights over Alaska and later also over Hawaii, and some other issues. ${ }^{6}$ Throughout, however, the United States continued to state in its Compliance Reports that the U.S. implementation record was clean.

Issues raised by the United States and listed as reasons for the withdrawal from OST have different status and relevance. Limit of flights over Kaliningrad and various other limitations (force majeure, altitudes, etc.) were directly related to OST. Russia justified the limit on flights over Kaliningrad by the need to limit interference with normal civilian air traffic 
as was the case during a 1500-km OST flight by Poland in April 2014. Another case in point cited by Russia is the precedent of a U.S.-imposed limit on flights over Alaska: Russia argued that even with that limit the density of coverage of the territory of Kaliningrad oblast was significantly higher than the same indicator for Alaska. ${ }^{7}$ Various other limitations that the United States claimed infringed on obligations under OST were more technical and, as admitted even by the U.S. Department of State, were "matters of interpretation".

Issues related to flights along the Russian borders with contested territories in the Caucasus as well as the refueling point in Crimea stemmed from broader disputes and were seen by the United States as attempts to impose the Russian interpretation of territorial conflicts onto other OST parties. By accepting a ban on flights along the Russian border with Abkhazia and South Ossetia and by using the refueling point in Crimea, Washington would have de facto accepted the Russian understanding of the status of these territories: quite obviously, preservation of OST was not a sufficient reason for such a fundamental change in the U.S. (and Western) positions. Such issues were hardly exclusive to Russia, though: Turkey, for example, introduced similar limitations on the OST flights over Cyprus, over whose status it remains in conflict with Greece. Conflict over the 10-km stretch along the southern border of Russia also resulted in Georgia's refusal, since 2012, to allow the Russian flights over its territory (which can also be classified as a violation of OST). In 2017, Georgia blocked an agreement over the distribution of flight quotas resulting in an interruption of the OST flights in 2018.

Territorial disputes within the OST context were perhaps unavoidable to the extent that they reflected larger and more fundamental conflicts of which OST became a hostage. In effect, Russia was bound to introduce the restriction because it recognized Abkhazia and South Ossetia as independent states whereas Western countries were bound to reject it because they recognized both as part of Georgia. Same as technical issues described above, the severity of these disagreements is subject to interpretation.

All or at least the majority of these issues could be resolved, with a minimal degree of cooperation in place, and Russia demonstrated it was prepared to find a compromise. For example, in February 2020, it allowed an observation flight over Kaliningrad by the United States, Lithuania, and Estonia that was somewhat longer than $500 \mathrm{~km}$ indicating it was prepared to relax the limit and increase it, perhaps not to the original level but longer than $500 \mathrm{~km}$. Some other concerns were removed, too, such as the altitude limit on flights over Chechnya. More generally, even U.S. Compliance Reports duly listed several instances when previously contested issues were recorded as resolved.

There was also an attempt to demonstrate flexibility with respect to flights along the borders with Abkhazia and South Ossetia: in 2018, Russia allowed such flights and at the same time did not file a request for an overflight of Georgia (a similar request in 2017 prompted Georgia's veto on the distribution of quotas in 2017), indicating it reserved the right to return to the issue of Georgia's ban on the Russian flights over its territory. In the absence of progress on the Russian flights over Georgia, Moscow restored the 10-km restriction in 2019 , but it was clear that the issue was not unresolvable. In the worst case, it could be relegated to the category of permanent disagreements, same as the Turkish claims on Northern Cyprus.

Implementation of treaties is rarely smooth and conflict-free, especially when it comes to treaties that are highly detailed and contain complex legal and technical provisions that seek to address every, even purely theoretical contingency. Life is always more complex 
and less predictable defying the wildest imagination of negotiators; consequently, disagreements over the interpretation of various specific provisions are bound to arise. For the purpose of addressing these disagreements, parties usually create dedicated mechanisms, usually in the form of commissions. It is also not uncommon that some issues remain unresolved, especially when they are caused by events extraneous to a specific treaty (the effects of territorial disputes on OST belongs to that category), and become constant irritants.

Whether implementation issues cause the treaty's collapse ultimately depends on the political decision of each state party. The pattern of parties' interaction within OST has not been positive in this respect. Although the crisis of OST has been commonly associated with the Trump administration, problems already emerged under his predecessor, Barack Obama. While during Obama's two terms the United States never formally charged Russia with violations of OST, it continuously listed "compliance concerns" over the Russian implementation record - a term that left room for resolution and, more importantly, continued functioning of OST. However, the U.S. administration also continued to insist on the validity of its interpretations and never recognized the validity of Russian concerns. This created a situation fraught with deadlock and, by contributing to the build-up of negative attitude towards OST in the U.S. domestic politics, de facto prepared grounds for the ultimate U.S. withdrawal. To clean its implementation record, Russia was expected to accept all U.S. interpretations which was not necessarily feasible on technical and legal grounds and, when it came to territorial issues, simply impossible for Moscow. Much as the United States and its allies were not prepared to change their position with respect to the status of Abkhazia, South Ossetia, and Crimea for the sake of OST, Russia would not relinquish its position on these issues for the sake of OST either.

Moreover, in 2016, the Obama administration was reportedly on the verge of formally accusing Russia of violation of $\mathrm{OST}^{9}$ that could have theoretically resulted in the U.S. withdrawal several years earlier. The threshold, however, was crossed by the Trump administration: the 2018 Compliance Report, the first one fully prepared by the new team, changed the term that characterized some of these issues from "compliance concerns" to "violations", 10 signaling the hardening of the U.S. position and effectively precipitating Washington's decision to withdraw from the treaty.

It would be a mistake to blame everything on the executive branch of the U.S. government, though. Congress made its own contribution severely complicating the implementation of the treaty. As Scott Anderson and Pranay Vaddi remarked, "since 2014, Congress has regularly inserted provisions relating to the treaty into the annual National Defense Authorization Acts (NDAAs), setting limits on the availability of funds for various treaty-related activities - including U.S. overflights, technical modifications to U.S. aircraft and sensors, and efforts by the OSCC [the Open Skies Consultative Commission - ed.] to change the types of sensors used for overflights - absent certain findings and certifications by executive branch officials". ${ }^{11}$

In 2013, the National Defense Authorization Act limited the freedom of the executive to accept any changes to the capabilities of OST observation aircraft. ${ }^{12}$ Notwithstanding, American diplomats continued to support upgrades to the equipment allowed on OST aircraft and in 2016 reported with considerable satisfaction that parties to OST accepted transition from film to digital sensors. ${ }^{13}$ Nonetheless, the 2018 NDAA expressly prohibited certification of infrared or synthetic aperture radars on such aircraft. ${ }^{14}$ In the end, the 
administration succeeded in moving forward on the certification issue and the new Russian aircraft was approved in early 2019.

The "certification saga" revealed the absence of consensus within the U.S. government on the future of OST, both between the legislative and the executive branches and within the executive branch. Even as the State Department officially pronounced Russia to be in violation of OST, the Department of Defense was lobbying for modernization of the U.S. OST aircraft. In the May 22, 2018 letter to Senator Deb Fisher, then-Secretary of Defense James Mattis insisted that, in spite of the Russian compliance record, the treaty remained in "the best interests" of the United States; that letter was sent only a month after the 2018 Compliance Report declared Russia in violation of OST. ${ }^{15} \mathrm{He}$ also complained that the U.S. aircraft used for OST flights were outdated and needed both regular and unplanned maintenance, often resulting in mission delays or cancellations, to the extent that in 2017 the United States was only able to complete 64 percent of scheduled flights over Russia. Equipment was outdated, too, including the use of wet-film cameras, which, in an era of digital imagery, was next to unthinkable for the United States. It is well known that Mattis did not win that fight and, after he left the Pentagon in early 2019, the treaty lost an important, albeit somewhat reluctant, ally in Washington.

Hidden behind compliance concerns was a more poisonous issue of the extent of data collected by the Russian aircraft during flights over the United States and its allies, which, many claimed, was too detailed to serve confidence-building purposes alone. In February 2016, Director of Defense Intelligence Agency Lieutenant General Vincent Stewart claimed in a testimony to the U.S. House of Representatives Armed Services Committee that Russia was collecting "incredible foundational intelligence on critical infrastructure, bases, ports, all of our facilities". ${ }^{16}$ Almost simultaneously, Commander of U.S. Strategic Command (STRATCOM) Admiral Cecil Haney called OST a "critical component of Russia's intelligence collection capability". ${ }^{17}$ It is noteworthy that these views emerged in public still on Obama's watch as yet another proof of the fact that opposition to OST preceded Donald Trump's tenure. Under Trump, these views became more pronounced and their proponents acquired greater influence on policy, but one cannot claim that the Obama administration seriously tried to save the treaty.

In theory, nothing prevented the United States from modernizing the OST aircraft, and, as noted above, some influential figures continued to favor that option. Yet, the administration chose the opposite track. In an official statement announcing the withdrawal from OST, U.S. Secretary of State Michael Pompeo put forward the following rationale for that decision: "Moscow appears to use Open Skies imagery in support of an aggressive new Russian doctrine of targeting critical infrastructure in the United States and Europe with precision-guided conventional munitions. Rather than using the Open Skies Treaty as a mechanism for improving trust and confidence through military transparency, Russia has, therefore, weaponized the Treaty by making it into a tool of intimidation and threat". ${ }^{18}$

Pompeo's statement also explained that the United States was not prepared to exercise its right to reequip its aging "OC-135" aircraft with new-generation sensors: "Doing that would only further undermine the core purpose of the Treaty, and create further tension and distrust between the United States and Russia. We will not contribute to further weaponizing and poisoning with distrust a Treaty that was intended to build confidence". ${ }^{19}$

These arguments were, in effect, a repetition of old Soviet concern that had led to the rejection of Dwight Eisenhower's initiative and proceeded from the belief that transparency 
only provides the opponent with militarily significant data and thus undermines the security of the country. This position stands in stark contrast to decades of the United States' push for greater openness. Reviving Eisenhower's Open Skies proposal, President George W. Bush called it a test of whether changes in Soviet domestic and foreign policies were genuine; under Obama and Trump, the United States certainly failed that test.

By the fall of 2019, reports emerged that the decision to withdraw had already been made $^{20}$ and, indeed, a formal announcement followed in May 2020 providing just enough time for the expiration of the six-month warning period prior to the end of Donald Trump's term as president (according to the treaty, notification about withdrawal takes effect only after a six-month period). There is little reason to believe that the timing was primarily dictated by that consideration, at least not as far as Donald Trump himself was concerned. He obviously intended to win the election in November 2020 and, from his perspective, the precise timing did not matter. It may be the case, however, that some high-level members of his administration and congressional leaders wanted to make sure that, regardless of the outcome of the election, the withdrawal was irreversible: if Trump were to lose the presidency, as it eventually happened, he would remain president until January 21, 2021, and the successor would have hard time to reverse Trump's decision.

Stepping outside the confines of the Open Skies Treaty, it is important to note that the sequence of events leading to the U.S. withdrawal from OST closely followed the fate of the 1987 Intermediate-Nuclear Forces (INF) Treaty, albeit with some delay. The patterns are remarkably similar:

- Public accusations of the Russian violations of INF emerged in 2014 ; for OST it was in 2016.

- In both cases, Russia was presented with a choice between accepting the U.S. charges at face value to the full extent and being pronounced in non-compliance and/or violation of the respective treaty; discussion of these charges and serious negotiations over a possible compromise solution were never seriously considered.

- Russia's own concerns were treated as artificial and not warranting serious discussion.

- All this meant that mechanisms created to address concerns, suspicions, and suspected violations were never utilized as they were supposed to.

- In both cases, Russia made proposals intended to alleviate the U.S. concerns. With respect to INF, for example, Moscow offered to conduct a demonstration of the missile that the United States and NATO believed was in violation of the treaty, but the U.S. and NATO representatives refused to participate. Russian proposals to address controversies in the OST context are described above. However, Russia's action probably came too late in both cases - by the time such proposals were made, it was too late to prevent the U.S. withdrawal from both treaties (for example, Russia allowed a flight over Kaliningrad in excess of $500 \mathrm{~km}$ only in January 2020, when the mind of the Trump administration had been already set).

- In both cases, during the endgame Russia downplayed its concerns and effectively removed them from consideration. It is difficult to say whether this was a tactical mistake (by downplaying its concerns, Russia effectively endorsed the U.S. refusal to address them), but in any event that move had to be either taken earlier, or perhaps not taken at all.

The latter similarity also applies to the extension of New START. For many years, Russia had serious concerns about the U.S. implementation record and even pronounced 
them a condition for the extension of the treaty. Yet, in January 2020, Moscow declared it was prepared to extend New START unconditionally. Such a change of heart always has the effect of weakening or even undermining someone's position: in the future, it would be difficult for Russia to maintain and enforce conditionalities. It is always best to either keep it until the end even at the expense of the desired outcome, or not announce it at all. In the case of New START, perhaps the latter was preferable.

The similarity between INF and OST brings to the fore once again the question of whether the Trump administration's approach to arms control constituted an aberration or was in line with long-term patterns of the U.S. behavior. The latter appears to be the case. Troubles with arms control treaties started during Obama's second term and may be causally linked to the deep crisis in the U.S.-Russian relations over events in Ukraine. Following the conclusion of New START in 2010, there was not much progress anyway: the parties even failed to begin negotiations on the next treaty as it was originally planned. However, in 2014, Obama failed to isolate arms control from the broader context. He did not engage in domestic political fights and instead allowed greater visibility and impact to arms control skeptics (as demonstrated by statements quoted above that OST was harmful to the U.S. national security) and adopted a harder line toward resolution of conflicts and alleviation of mutual concerns.

The Obama administration's attitude toward arms control can best be described as procrastination: it did not purposefully make things worse, but did not try to stabilize the treaties either and seemed to prefer waiting for whatever happens. Obviously, the election of Donald Trump almost instantly changed the dynamic: instead of indecision, it embarked on an energetic, consistent, and definitive policy of withdrawal.

\section{The broader context: problems and prospects of cooperation on arms control}

If Donald Trump's policy was not an aberration but, instead, a manifestation of a longer-term political trend taken to the extreme, then the future of arms control in general and OST in particular may not be as bright as expected by some after the election of Joe Biden as the U.S. president. The Biden administration was quick to reverse some decisions of its predecessors, which was welcome news. Within days, Biden extended the U.S.-Russian New START Treaty, brought the United States back to the Paris Agreement on climate change, and began negotiations on the U.S. return to Joint Comprehensive Plan of Action (JCPOA) that established verifiable limits on the Iranian nuclear program (at the time of writing, negotiations were not concluded, but were progressing in a satisfactory manner). The new administration, however, decided not to return to OST, ${ }^{21}$ which would remain an irreparable loss from the Trump years.

The fate of OST is but one manifestation of a broader trend in the U.S.-Russian and NATO-Russian arms control processes. According to traditional understanding, arms control involves cooperation between adversaries for the purpose of stabilizing military balance and preventing war, at least a large-scale war or, preferably, any kind of military confrontation which can escalate to a large-scale war. Given the centrality of the task for sheer survival, it is always desirable to isolate it from the impact of other disagreements and conflicts. Arms control may have an impact on other domains but it has always been limited and has never resulted in a fundamental change in the relationship. 
Arms control achieves its goals through measures that limit the ability of each side to win war. In the strategic nuclear domain, this requirement is operationalized as absence of an assured first-strike capability (each side retains ability to respond under any reasonable scenario of conflict). In the conventional forces domain, this goal is achieved through reduction of concentration of forces along the common border.

Confidence-building measures (CBMs) are part of the arms control toolbox: they do not provide for reductions or limitations of armaments of troops, but help provide each side with reasonably reliable data about military activities of the other and its military capabilities. By doing that, CBMs help ascertain that parties are not engaged in secret buildup of forces and that large-scale military activities, such as maneuvers, are not preparations for an attack in disguise. OST belongs to the CBMs and has been a relative success, for instance when it was used by the United States and NATO in 2014 to monitor the situation in Eastern Ukraine and thus de facto expanded into the political issue-area.

Transparency is traditionally regarded as an important component and even a precondition for cooperation. Indeed, without reliable data about capabilities and activities of the other side, arms control would hardly be possible as adversaries do not merely trust statements of the other side. National technical means, a term that in the arms control context usually defines independent data collection capability such as satellites, have limited utility in the absence of cooperation of the other side. Transparency, however, is a double-edged sword: when a state provides too much data, it risks undermining its security, but when it provides too little data, it risks undermining cooperation. Finding the middle ground is always difficult, is usually achieved ad hoc, and always involves intense bargaining both inside each country and between states. ${ }^{22}$

Domestic bargaining can be especially difficult and even brutal. Successful interstate negotiations require strong commitment of the executive power and major investment of political capital into supporting ongoing negotiations with another country to push through the domestic process the outcome of these negotiations. After all, interstate negotiations almost always require compromises, which many inside the country may not like. Examples of negotiating "victory" in the sense of complete or near-complete achievement of preferences of one of the sides are rare and even more rarely survive the test of time. This is what happened to the 1993 START II Treaty: under specific international conditions of 1992 when negotiations took place, the United States succeeded in achieving almost all its goals, but only a few years later the domestic political situation in Russia changed and the treaty became unratifiable.

The U.S. approach to arms control in the 21st century, starting with the George W. Bush administration, has been characterized by reluctance or even unwillingness to invest in domestic politics of arms control. During the Cold War and the first post-Cold War decade, all U.S. administrations demonstrated strong commitment to arms control regarded as a tool of preventing war and thus central to the national security of the United States. Over time, however, that commitment began to decline. One can even say that the fear of war began to dissipate. As a result, political capital was spent on other issues - perhaps, worthy and urgent ones - at the expense of arms control. One of the first expressions of such attitude was ratification of the Comprehensive Test Ban Treaty (CTBT) in the United States in the end of 1990s when the Clinton administration chose not to undertake a serious effort to push the treaty through the Senate. As a result, the treaty was 
not ratified and now the prospects of its ratification appear close to zero and perhaps even non-existent.

Likewise, opponents of arms control in general or of specific past agreements (who exist in any country, including Russia) acquired greater visibility and political relevance. Past agreements that necessarily involved compromises, often difficult and undesirable, were subjected to attacks and their political support inside the country declined. It certainly did not help that some administrations, such as that of George W. Bush, actually shared that sentiment and believed that past arms control achievements were outdated or too restrictive. During the George W. Bush years, this sentiment led to the U.S. withdrawal from the 1972 Anti-Ballistic Missile (ABM) Treaty that limited strategic missile defense systems of the United States and Russia. This led to another form of arms race: the United States continued to pursue advanced missile defense capability (the project that two decades later shows very modest results) while Russia embarked on development of offensive weapons capable of penetrating future U.S. missile defense. Another example of an attempt to revise the Cold War arms control experience was the pursuit of less restrictive and less verifiable measures. The 2002 Strategic Offensive Reductions Treaty (SORT) represented a glaring example of that approach - it contained only nominal restrictions and no verification.

Effectively, in the place of the Cold War rule "I agree to limit myself so that I can limit you", the George W. Bush team introduced the opposite approach: "l'd rather not limit you if this is necessary to avoid limiting me". In other words, absence of arms control was preferable to limitations on the U.S.' own programs and forces. Underlying this approach was the belief that the United States was sufficiently advanced to remain ahead of any possible competitors, including Russia, and its military capability would always remain dominant. This does not mean that the G.W.Bush administration was "pro-nuclear" or sought to use military preponderance to gain political advantages. In fact, he presided over the largest unilateral reduction of American nuclear stockpile. Rather, the U.S. government believed that opponents should accept U.S. military dominance and share the assumption about American benevolence on the world stage. Of course, things do not work that way and, as mentioned above, this led to a de facto qualitative arms race that few were prepared to openly define as such.

The Obama administration sought to quickly fix a major drawback of its predecessor: the 1991 START I Treaty was set to expire in less than a year and with it the United States would lose the entire system of transparency and verification measures. The system of limits established by that treaty no longer mattered as both sides significantly reduced their strategic forces well below the START I limits, but transparency continued to rest on START I. The Obama administration quickly embarked on negotiations on a replacement treaty and, in the spring of 2010, New START was signed. The treaty faced stiff opposition in the Senate and the administration had to accept tight conditions for any follow-on talks as the price of ratification. Since then, the two countries failed to launch new negotiations: the Obama administration was only prepared to negotiate on issues that did not face serious domestic opposition (such as reduction of nuclear weapons) whereas Russia insisted on addressing other issues it believed were vital for strategic balance, such as missile defense and long-range precision-guided conventional weapons. Since these Russian additions to the agenda were not compatible with the U.S. domestic political lineup, the Obama administration preferred not to launch negotiations to investing in changing that lineup. 
In short, the Obama administration was undoubtedly supportive of arms control, but was not prepared to seriously invest into its success after conclusion of New START. The passive stance on the domestic political scene resulted not only in the absence of new negotiations (which, under the next administration, forced the two countries to consider extension of New START instead of the original plan to replace it with a new treaty), but also gave more prominence to the opposition to, and the overall weakening of, arms control in general.

The Obama administration also presided over a new approach to resolution of conflicts over implementation of treaties - perhaps, also as a result of its reluctance to tackle difficult and politically controversial decisions. As described above, the new approach amounted to an ultimatum to Russia: "admit violations and fix them the way we say they should be fixed". Such an approach, determined by the feeling of righteousness and moral superiority, almost never works; instead, such issues are more effectively addressed through detailed, often difficult negotiations and a compromise. When the INF controversy came into the open, chances for successful resolution became practically non-existent. Two years later, the same happened to OST.

Against this background, the Trump administration's approach to arms control does not look like an aberration (except for certain nuances in style). It did not appear to be averse to arms control as a matter of principle: instead, Trump's key decision-makers were opposed to the old agreements inherited from the Cold War and were prepared to negotiate new ones that would not limit the U.S. freedom of action. In this sense, Trump's approach was quite similar to that of the George W. Bush administration. Once again, the guiding principle was: either progress on the U.S. terms or no progress at all; both options were equally acceptable.

At the time of writing, it is too early to say much about the Biden administration's approach to arms control. The administration quickly moved to extend New START for the maximum term of five years without preconditions, which in itself was positive news. However, this step is of limited relevance for understanding future policy. The new team was also quick to announce that it would seek to isolate arms control from the broader context of the troubled U.S.-Russia relationship, which could be a return to the practice typical for the Cold War years (and was one of the conditions for success of negotiations at the time) and as such represents a positive sign, too. The arms control process may restart.

It remains to be seen if Joe Biden is able to fully repair the damage done under his predecessor. The OST has been absent from Biden's short-term agenda. On March 31, 2021, Washington informed its NATO partners that the United States would not rejoin the treaty because this would "send the wrong message to Russia" in light of the Russian violations $^{23}$ and in the end of May informed Russia of that decision. It is difficult to say whether this is a genuine reason (that means that the Biden administration would be following in the footsteps of its two predecessors, Obama and Trump), or perhaps the political price of returning to the treaty was thought to be so high that it would impede other plans. There has been a discussion of legal options, but it appears that the only feasible way to return to OST is to send the treaty back to the Senate for ratification, ${ }^{24}$ an option that is unlikely to succeed. Either way, the United States will not return to OST. 


\section{Russia on the path toward withdrawal}

Details of the Russian withdrawal from OST are addressed in another article in this issue. ${ }^{25}$ Here it is important to note only several key features that illuminate the evolving Russian approach to interaction with the United States on arms control.

There is little reason to doubt that, following a period of uncertainty about the value of OST, Russia embraced the regime. The commissioning of specially equipped aircraft for these purposes serves as strong evidence that Moscow planned that the treaty would remain in force for many years. The negative attitude of the Trump administration toward OST and rumors about potential U.S. withdrawal caught Russia off guard, it seems. It also appears that Moscow regarded American concerns with respect to the Russian implementation record as a matter of routine - something that happens with every treaty and does not warrant a withdrawal.

That said, the Russian attitude toward these and similar issues definitely hardened compared to 1990s: Moscow felt more empowered to reject them or to introduce various limitations where it saw them desirable. It also displayed greater proficiency in interpreting legal language to its advantage ("playing legal games"), a big change compared to the Soviet times. According to the standard pattern known since the height of the Cold War, all these issues - both American and Russian concerns - should have remained on the table for a very long time, perhaps indefinitely, as long as the core of the treaty remained intact and the balance between rights (benefits) and restrictions continued to be firmly in favor of the former. The certification of new Russian aircraft in the early 2019 could be seen as a confirmation of that view. This probably explains why Russian attempts to resolve at least the more visible issues, such as the 500-km limit on overflights of Kaliningrad oblast, came late in the game, months after rumors about pending U.S. withdrawal appeared and only shortly before the actual withdrawal.

During the six-month period between the U.S. notification about its intention to withdraw and the actual withdrawal, Moscow had to make a difficult decision on whether it would follow the example. The decision to withdraw was not preordained and the door remained half-open until the last moment. Yet, an important evolution of the Russian position took place as well.

Initially, one could hear voices advocating Russia remaining in OST. A Foreign Ministry statement in connection with the U.S. declaration of intention to withdraw declared that, in spite of the U.S. decision, "Russia believes that OST is useful for all its parties. It facilitates the strengthening of confidence and, consequently, of European security". ${ }^{26}$ Similar views were expressed by the expert community: two leading Russian experts, Yevgeni Buzhinski and Oleg Shakirov, claimed that "the benefits of continued participation of Russia in OST outweigh the losses caused by the US withdrawal". They pointed out that the vast majority of Russian Open Skies flights were over Europe and only 14 percent of them were over the United States. Given NATO's growing military capability vis-à-vis Russia, such flights would serve Russia's interest, they wrote. ${ }^{27}$

Indeed, according to a European expert on OST, Alexander Graef, since the entry of OST into force in 2002, Russia conducted only 77 flights over the United States whereas the United States conducted 181 flights over Russia and Belarus. ${ }^{28}$ In this sense, the change in the data Russia was collecting within the context of OST would be modest. 
The mood changed by the summer of 2020. Speaking in June, Foreign Minister Sergey Lavrov indicated that the Russian withdrawal from OST was not impossible and declared that "the key condition for our ratification of the Treaty on Open Skies was a possibility to survey the United States' territory". ${ }^{29}$ This was a clear declaration that Moscow considered continuation of its membership in OST without the United States untenable.

The rationale behind that position is not completely clear. The initial reaction was based on cool-headed calculation of the benefits Russia derived from OST flights. These calculations did not change by the end of June. Rather, the decision seemed to be political: if the United States were bent on undermining an important international regime, Russia would not simply go along. Without doubt, the U.S. previous withdrawals from the ABM Treaty and especially the INF Treaty played their role as well.

Judging by subsequent events, Moscow was also guided by the following rationale: by withdrawing from OST, the United States would deny data about itself to Russia, but would still keep access to all data about Russia through its allies. In other words, the United States will only get benefits and no costs. By withdrawing from OST, Russia could impose costs on the United States and its allies even though it also meant costs for itself. As noted above, the Trump administration's decision to withdraw from OST was hardly dictated by this type of cost-benefit analysis and was more ideological than practical; yet, this seemed to be how Russia rationalized that decision.

As a result, Russia decided to link its continuation as a party to OST to an explicit obligation of other parties not to share information obtained from the OST flights with the United States; that condition was announced by deputy foreign minister Sergey Ryabkov at the Fourth OST Review Conference in October 2020. ${ }^{30}$ That position was vulnerable on two counts: first, the treaty allowed sharing data only among parties, hence a special declaration to that effect did not appear strictly necessary and, second, even with that obligation, European NATO countries (at least some of them) would still be able to share data with the United States, perhaps, not in the form of raw data from flights, but as part of broader intelligence exchange within NATO.

In other words, Moscow was after a political decision by other parties to OST rather than about substance. European NATO countries expressed their regret, but did not seriously attempt to bring Washington back on board and thus, in Moscow's view, bore part of the blame for the American withdrawal. Typical Western interpretation of that position Russia's perceived attempt to split NATO - is questionable. Rather, it was Russia's message to the Europeans: if you value OST, you also need to do something to preserve it. The message did not completely fall on deaf years: some European security experts insisted that Europe, indeed, needs to find its own voice with respect to arms control. ${ }^{31}$ This belief, however, did not extend to governments that effectively took the position that Russia should preserve OST by remaining a party in spite of the U.S. withdrawal.

The follow-up was somewhat mind-boggling. Russia intended to discuss its request during the next regular meeting of parties to OST on January 25, 2021, but then suddenly issued an ultimatum that state parties should confirm their agreement not to share data with the United States by January 1, 2021 or Russia will begin withdrawal procedures. It is hardly surprising that European countries rejected that ultimatum. ${ }^{32}$ Effectively Russia lost an opportunity to nudge Europeans toward a more proactive position. It is far from obvious that such an attempt could succeed, but now that option was closed. 
Following that altercation, Moscow shifted the onus to the new team in the White House. On January 15, 2021, five days before the inauguration of Joe Biden as president of the United States, Russia announced it was beginning internal procedures for the withdrawal from OST. ${ }^{33}$ Shortly thereafter, Sergey Lavrov declared that Russia would remain in OST if the United States returned to it. ${ }^{34}$ Considering the Biden administration's intention to extend New START and hints about its return to the JCPOA, such a calculation was not unfounded, at least at the initial phase.

The complicated and time-consuming Russian constitutional procedure for withdrawal from international treaties, that required the consent of the parliament, gave the United States and its allies plenty of time to react. In fact, the formalities within the executive branch of the Russian government took several months (considering that similar procedure used for New START extension took only several days, this cannot be classified other than intentional delay). Throughout that time, the Russian government missed no opportunity to remind the West about the chance to save OST. The last such reminder came on May 3, 2021, as the issue was sent to the State Duma: head of the Russian delegation on military security and arms control, Konstantin Gavrilov, announced that the West had only one month left to make up its mind. ${ }^{35}$ Indeed, the Duma ratified the Russia's withdrawal from OST on May 19 and the Federation Council followed suit on June 2. Yet, this did not mean that Russia would withdraw right away: if anytime in June 2021 Russia submits a notification about its decision to withdraw, the actual withdrawal will happen in six months, i. e., no sooner than in November 2021. Thus, there is still plenty of time to save OST, if the Biden administration changes its mind, but this does not appear feasible.

\section{Conclusion}

The pending collapse of OST represents yet another instance of gradual dismantlement of the network of arms control and confidence building regimes created at the end of the Cold War. Perhaps, these regimes were imperfect and not sufficiently adequate in the current environment, but their demise leaves a vacuum and an environment of increasing uncertainty - a truly dangerous development in an era of growing tensions.

This largely resulted from changes in the U.S. approach to arms control that developed slowly over the first two decades of the 21 st century. While policies changed from one president to another, a sequence of the U.S. administrations shared growing loss of interest in arms control and unwillingness to invest in generating domestic support for existing and new agreements. The case of OST is particularly unfortunate, as it was one of agreements to which Russia seemed truly committed.

Whether the hole created by the demise of OST can be filled with a new agreement or by expanding the scope of existing ones remains uncertain. With the passing of some arms control regimes and the failure to update others, the task becomes ever more monumental. In any event, it is clear that the Open Skies idea has come to its end. There is little chance that the OST aircraft will fly ever again. There may perhaps be other ways to provide the same level of transparency, but the last page on the first confidence-building concept is to be turned. 


\section{ENDNOTES}

${ }^{1}$ For background on the treaty, see Jones P. Open Skies: Transparency, Confidence-Building, and the End of the Cold War. - Palo Alto (Calif.): Stanford University Press, 2014; Spitzer H. The Open Skies Treaty: a cooperative approach to confidence-building and verification // The Weapons Legacy of the Cold War: Problems and Opportunities. Eds. D.Schroeer and A.Pascolini. - London: Routledge, 2018. P. 163-176; Jones P. Making a Better Treaty on Open Skies. James Martin Center for Nonproliferation Studies (CNS), Middlebury Institute of International Studies at Monterey. CNS Occasional Paper No. 50. February 2021. URL: https://nonproliferation.org/wpcontent/uploads/2021/02/making_a_better_open_skies_treaty.pdf (accessed 05.06.2021). More broadly on verification through aerial monitoring, see Lindley J. Cooperative airborne monitoring: opening the skies to promote peace, protect the environment, and cope with natural disasters // Contemporary Security Policy. V. 27. No. 2. 2006. P. 325-343.

${ }^{2}$ Adherence to and Compliance with Arms Control, Nonproliferation, and Disarmament Agreements and Commitments. U.S. Department of State. Bureau of Arms Control, Verification and Compliance Report. 5 June 2015. URL: https://2009-2017.state.gov/t/avc/rls/rpt/2015/243224.htm (accessed 15.04.2021).

${ }^{3}$ Adherence to and Compliance with Arms Control, Nonproliferation, and Disarmament Agreements and Commitments, U.S. Department of State. Bureau of Arms Control, Verification and Compliance Report. 31 July 2014. URL: https://2009-2017.state.gov/t/avc/rls/rpt/2014/230047.htm (accessed 15.04.2021).

${ }^{4}$ Adherence to and Compliance with Arms Control, Nonproliferation, and Disarmament Agreements and Commitments. 2014; Adherence to and Compliance with Arms Control, Nonproliferation, and Disarmament Agreements and Commitments. 2015; Adherence to and Compliance with Arms Control, Nonproliferation, and Disarmament Agreements and Commitments. U.S. Department of State. Bureau of Arms Control, Verification and Compliance Report. 11 April 2016. URL: https://2009-2017.state.gov/t/avc/rls/rpt/ 2016/255651.htm (accessed 15.04.2021).

${ }^{5}$ Vienna Document is an agreement among parties to the Organization on Security and Cooperation in Europe (OSCE) on transparency and confidence-building measures. The first Vienna Document was adopted in 1990 and was periodically updated; the current version was adopted in 2011.

${ }^{6}$ For details of the Russian position with respect to disagreements over the implementation of OST, including Russia's concerns, see: Treaty on Open Skies: Questions and Answers. Ministry of Foreign Affairs of the Russian Federation. 26 May 2020. URL: https://www.mid.ru/en/diverse/-/asset_publisher/zwl2FuDbhJx9/content/dogovorpo-otkrytomu-nebu-voprosy-i-otvety?_101_INSTANCE_zwI2FuDbhJx9_redirect=https\%3A\%2F\%2Fwww.mid.ru \%2Fen\%2Fdiverse\%3Fp_p_id\%3D101_INSTANCE_zwI2FuDbhJx9\%26p_p_lifecycle\%3D0\%26p_p_state\%3Dnormal \%26p_ p_mode\%3Dview\%26p_p_col_id\%3Dcolumn-1\%26p_p_col_pos\%3D2\%26p_p_col_count\%3D6 (accessed 10.12.2021).

${ }^{7}$ Ibid.

${ }^{8}$ Adherence to and Compliance with Arms Control, Nonproliferation, and Disarmament Agreements and Commitments. August 2019. - Washington D.C.: U.S. Department of State, 2019. URL: https://www.state.gov/wpcontent/uploads/2019/08/Compliance-Report-2019-August-19-Unclassified-Final.pdf (accessed 03.11.2020).

${ }^{9}$ Forrest B., Hodge N. In tiff with Russia, U.S. moves to restrict international military flights over Hawaii // The Wall Street Journal, 28 September 2017.

${ }^{10}$ Adherence to and Compliance with Arms Control, Nonproliferation, and Disarmament Agreements and Commitments. April 2018. - Washington D.C.: U.S. Department of State, 2018. URL: https://2017-2021.state.gov/ 
2018-report-on-adherence-to-and-compliance-with-arms-control-nonproliferation-and-disarmament-agreementsand-commitments/index.html (accessed 03.11.2020).

${ }^{11}$ Anderson S.R., Vaddi P. When Can President Withdraw from the Open Skies Treaty? Carnegie Endowment for International Peace Commentary. 22 April 2020. URL: https://carnegieendowment.org/2020/04/22/when-canpresident-withdraw-from-open-skies-treaty-pub-81623 (accessed 01.02.2021).

${ }^{12}$ National Defense Authorization Act for Fiscal Year 2015. Pub. L. No. 113-29, sec. 1242.

${ }^{13}$ Adherence to and Compliance with Arms Control, Nonproliferation, and Disarmament Agreements and Commitments. 2016.

${ }^{14}$ National Defense Authorization Act for Fiscal Year 2019. Pub. L. No. 115-232, sec. 1242.

15 The text of the letter can be found at URL: https://www.fischer.senate.gov/public/_cache/files/b2df2cf7-38284d81-aa57-2963ce8d70b0/sd-response-to-senator-fischer-regarding-the-open-skies-treaty-osd070739-18.pdf (accessed 10.02.2021).

${ }^{16}$ Worldwide Threats. Testimony by Lieutenant General Vincent R. Stewart, USMC Director, before the U.S. House Committee on Armed Services. 2 March 2016. [Video]. URL: https://www.youtube.com/watch?v=5IE9IZq9bIA (accessed 01.03.2021).

${ }^{17}$ Quoted in: Krepon M. In Defense of the Open Skies Treaty. The Stimson Center Commentary. Space Security Program. 7 March 2016. URL: https://www.stimson.org/2016/defense-open-skies-treaty (accessed 13.01.2021).

18 Pompeo M.R. On the Treaty on Open Skies. U.S. Department of State. Press Statement. 21 May 2020. URL: https://ru.usembassy.gov/secretary-pompeo-on-the-treaty-on-open-skies (accessed 01.02.2021).

19 Ibid.

${ }^{20}$ Graff G.M. Trump takes aim at a critical Cold War treaty with Russia // Wired. 10.08.2019. URL: https://www.wired.com/story/trump-open-skies-withdrawal (accessed 10.12.2020).

${ }^{21}$ Lee M. U.S. tells Russia it won't rejoin Open Skies arms control pact // Associated Press. 27.05.2021. URL: https://apnews.com/article/donald-trump-europe-russia-government-and-politics-69038e96de8488f2c 759b126c27d1366 (accessed 28.05.2021).

${ }^{22}$ Any international negotiations involve bargaining both in the domestic political process and at the interstate level; the two processes are interconnected and can be mutually reinforcing or, instead, undermine regime creation and maintenance. This process is described by the theory of "two-level games". See Putnam R. Diplomacy and domestic politics: the logic of two-level games // International Organization. V. 42. № 3. P. 427-460.

${ }^{23}$ Gould J., Mentha A. Rejoining Open Skies would "send wrong message" to Russia, State tells partners // Defense News. 7 April 2021. URL: https://www.defensenews.com/breaking-news/2021/04/07/rejoining-open-skies-wouldsend-wrong-message-to-russia-says-us-state-department/\#.YG3\%E2\%80\%A6 (accessed 01.05.2021).

${ }^{24}$ Rademaker S. Are there shortcuts for the U.S. to rejoin the Open Skies Treaty? // Lawfare Blog. 15.01.2021. URL: https://www.lawfareblog.com/are-there-shortcuts-us-rejoin-open-skies-treaty (accessed 01.02.2021). The author worked on arms control during the George W. Bush administration and his views are representative of a conservative perspective that is most likely to dominate in the Senate. Moreover, Congress (including legislators who may be supportive of the U.S. return to OST) always guards its prerogatives vis-à-vis the executive power and is unlikely to allow the U.S. administration to circumvent it. 
25 See an article by Dmitri Stefanovich in this issue: Stefanovich D. Dogovor po otkrytomu nebu: rossiiskiye vzglyady na problemy i varianty ikh resheniya [Open Skies Treaty: the Russian approaches to related problems and their possible solutions] // Pathways to Peace and Security. № 1(60). 2021. P. 151-161.

26 Treaty on Open Skies: Questions and Answers.

27 Buzhinski Ye., Shakirov O. Rossii sleduyet zayavit' o gotovnosti ostatsya v rezhime otkrytogo neba [Russia should declare its readiness to remain within the Open Skies regime] // Kommersant-Daily, 22 May 2020.

28 Graef A., Kütt M. Visualizing the Open Skies Treaty [web-site]. Institute for Peace Research and Security Policy at the University of Hamburg. Last updated 27 April 2020. URL: https://www.openskies.flights (accessed 30.04.2021).

29 Russia excludes no steps on its part at conference on Open Skies Treaty - Lavrov // TASS. 23.06.2020. URL: https://tass.com/politics/1170857 (accessed 01.03.2021).

${ }^{30}$ Statement of the Deputy Minister of Foreign Affairs of the Russian Federation Sergey Ryabkov at the Opening of the 4th Open Skies Treaty Review Conference. Ministry of Foreign Affairs of the Russian Federation. 7 October 2020 URL: https://www.mid.ru/ru/foreign_policy/news/-/asset_publisher/cKNonkJE02Bw/content/id/4373037 (accessed 01.02.2021).

31 Berghofer J. As Open Skies Falls Apart, Europe Need to Find its Voice. European Leadership Network Commentary. 12 May 2021. URL: https://www.europeanleadershipnetwork.org/commentary/as-open-skies-fallsapart-europe-needs-to-find-its-voice (accessed 15.05.2021).

32 Von Krüger P.-A., Mascolo G. Der Himmel könnte sich schließen // Suddeutche Zeitung. 3 Januar 2021.

33 Statement by the Ministry of Foreign Affairs of the Russian Federation on the Beginning of Domestic Procedures for the Withdrawal of the Russian Federation from the Treaty on Open Skies. Ministry of Foreign Affairs of the Russian Federation. 15 January 2021. URL: https://www.mid.ru/ru/foreign_policy/news/-/asset_publisher/ cKNonkJE02Bw/content/id/4522563?p_p_id=101_INSTANCE_cKNonkJE02Bw\&_101_INSTANCE_cKNonkJE02Bw_la nguageld=en_GB (accessed 01.02.2021).

34 Foreign Minister Sergey Lavrov's remarks and answers to questions at a joint news conference following talks with OSCE Chairperson-in-Office, Minister of Foreign Affairs of Sweden, Ann Linde, Moscow. Ministry of Foreign Affairs of the Russian Federation. 2 February 2021. URL: https://www.mid.ru/ru/foreign_policy/news//asset_publisher/cKNonkJE02Bw/content/id/4550431?p_p_id=101_INSTANCE_cKNonkJE02Bw\&_101_INSTANCE_c KNonkJE02Bw_languageld=en_GB (accessed 30.04.2021).

35 Postnikova Ye. U SShA poka est' mesyats na razdum'ya [The United States has a month for reflection] // Izvestia. 3 May 2021. 


\section{BIBLIOGRAPHY}

(2019). Adherence to and Compliance with Arms Control, Nonproliferation, and Disarmament Agreements and Commitments. Washington D.C.: U.S. Department of State. August. 66 p.

URL: https://www.state.gov/wp-content/uploads/2019/08/Compliance-Report-2019-August-19Unclassified-Final.pdf (accessed 03.11.2020).

(2018). Adherence to and Compliance with Arms Control, Nonproliferation, and Disarmament Agreements and Commitments. Arms Control, Verification and Compliance Bureau Report. Washington D.C.: U.S. Department of State. April. 45 p. URL: https://2017-2021.state.gov/wp-content/uploads/2019/ 05/AVC-2018-Compliance-Report.pdf (accessed 03.11.2020).

Anderson S.R. and Vaddi P. (2020). When Can President Withdraw from the Open Skies Treaty? Carnegie Endowment for International Peace Commentary. 22 April.

URL: https://carnegieendowment.org/2020/04/22/when-can-president-withdraw-from-open-skiestreaty-pub-81623 (accessed 01.02.2021).

Berghofer J. (2021). As Open Skies Falls Apart, Europe Need to Find its Voice. European Leadership Network Commentary. 12 May. URL: https://www.europeanleadershipnetwork.org/commentary/asopen-skies-falls-apart-europe-needs-to-find-its-voice (accessed 15.05.2021).

Gould J. and Mentha A. (2021) Rejoining Open Skies would "send wrong message" to Russia, State tells partners. Defense News. 7 April. URL: https://www.defensenews.com/breaking-news/2021/04/07/ rejoining-open-skies-would-send-wrong-message-to-russia-says-us-state-department/\#.YG3\% E2\%80\%A6 (accessed 01.05.2021).

Graef A., Kütt M. (2020). Visualizing the Open Skies Treaty [web-site]. Institute for Peace Research and Security Policy at the University of Hamburg. 27 April. URL: https://www.openskies.flights (accessed 30.04.2021).

Jones P. (2021). Making a Better Treaty on Open Skies. James Martin Center for Nonproliferation Studies (CNS), Middlebury Institute of International Studies at Monterey. CNS Occasional Paper No. 50. February 2021. 25 p. URL: https://nonproliferation.org/wp-content/uploads/2021/02/making_a_ better_open_skies_treaty.pdf (accessed 05.06.2021).

Jones P. (2014). Open Skkies: Transparency, Confidence-Building, and the End of the Cold War. Palo Alto (Calif.): Stanford University Press. 264 p.

Krepon M. (2016). In Defense of the Open Skies Treaty. The Stimson Center Commentary. Space Security Program. 7 March. URL: https://www.stimson.org/2016/defense-open-skies-treaty (accessed 13.01.2021).

Lindley J. (2006). Cooperative Airborne Monitoring: Opening the Skies to Promote Peace, Protect the environment, and Cope with Natural Disasters. Contemporary Security Policy. V. 27. No. 2. 325343. DOI: $10.1080 / 13523260600821517$.

Putnam R. (1988). Diplomacy and Domestic Politics: The Logic of Two-Level Games. International Organization. V. 42. No. 3. 427-460.

Spitzer H. (2018). The Open Skies Treaty: A Cooperative Approach to Confidence-Building and Verification. In The Weapons Legacy of the Cold War: Problems and Opportunities. Eds. D.Schroeer and A.Pascolini. London: Routledge. 163-176.

Stefanovich D. (2021). Dogovor po otkrytomu nebu: rossiiskiye vzglyady na problemy i varianty ikh resheniya [Open Skies Treaty: the Russian Views on Related Problems and Possible Solutions]. Pathways to Peace and Security. No. 1(60). 151-161. DOI: 10.20542/2307-1494-2021-1-151-161. 